\title{
Evaluating the Effects of Radio-Frequency Treatment on Rock Samples: Implications for Rock Comminution
}

\author{
Arthur James Swart \\ Vaal University of Technology \\ Republic of South Africa
}

\section{Introduction}

"You find remedy in the thorniest tree". This Arabic proverb well illustrates that scientific solutions to well defined engineering problems are often hard to find, resulting in much frustration and anguish. This has also proved true in the mineral processing industry, where numerous exigent scientific endeavours have sought to improve rock comminution. Comminution may be divided into two steps; the reduction of large materials to a size suitable for grinding (termed crushing) and the reduction of crushed material into powder (termed grinding or milling). Comminution efficiency is currently low and is based on the absolute ratio of energy required to generate new surface area relative to the total mechanical energy input (Tromans, 2008). Current comminution techniques need to be enhanced if a higher efficiency is to be realized.

Mineral liberation efficiency subsequently relates to the amount of energy required to release a certain percentage of valuable minerals from the gangue (waste material) through rock comminution methods. The major source of this energy generation is fossil fuels, coal, natural gas and oil, which are still expected to meet about $84 \%$ of energy demand in 2030 (Shafiee \& Topal, 2009). However, concerns continue to be raised regarding the burning of fossil fuels as a contributor to rising atmospheric concentrations of carbon dioxide $\left(\mathrm{CO}_{2}\right)$, which may contribute to climate change (Wolde-Rufael, 2010). Furthermore, it is estimated that in a mining-intensive country, the minerals processing industry accounts for approximately $18 \%$ of the national energy consumption. This process is currently inherently inefficient, with less than $3 \%$ of the energy input directly involved in rock breakage and liberation (Moran, 2009). Subsequently, the importance of coal in energy generation and as a possible source of global warming necessitates the use of alternative methods to reduce the amount of energy used by mining industries (increased power efficiency) while at the same time recovering the same (or higher) percentage of valuable minerals (higher throughput) (Wang \& Forssberg, 2007). This thorny dilemma continues to frustrate researchers around the globe within the fields of Metallurgical, Mechanical and Electrical Engineering.

Current research studies have found that the mineral liberation process can be enhanced through the use of pulsed power, ultrasound pre-treatment and microwave pre-treatment of 
run of mine ore (Gaete-Garretón et al., 2000; Wilson et al., 2006; Jones et al., 2007; Wang \& Forssberg, 2007). Ore, from the mining operation, goes through a process that separates the valuable minerals from the gangue. This process usually involves crushing, grinding (or milling), separation and extraction where the gangue is usually discarded in tailings piles (Perkins, 1998). These electrical methods, which are used to enhance the mineral liberation process, each have their own advantages and disadvantages, which are discussed in this chapter. However, this research proposes a different technique involving radio-frequency (RF) power, which may have positive implications for rock comminution and mineral liberation.

The main purpose of this research is to evaluate the effect that RF power exerts on rock samples, with particular focus on textural changes. This evaluation aims to determine if RF power weakens mineral grain boundaries, subsequently leading to improved rock comminution and mineral liberation. This may result in significant reductions of energy consumption of current comminution and mineral liberation equipment. This chapter will firstly define rock comminution and mineral liberation. Rocks used in this research are then presented along with current electrical treatment techniques which are applied to enhance rock comminution. A proposed new technique is substantiated with the practical setup of the equipment being introduced. Results of treating specific rock samples with RF power are presented quantitatively (electrical properties, surface temperature rise, particle screen analysis and SEM photomicrographs).

\section{Rock comminution and mineral liberation}

The processes used for the purification and enhancement of an ore, to satisfy the needs of downstream applications, are collectively referred to as mineral beneficiation (De Waal, 2007). The aim of mineral beneficiation is to separate ore minerals from gangue minerals, producing as pure as possible a concentrate of ore minerals distinct from tailings. The process is undertaken in steps where the run of mine ore first undergoes comminution followed by separation/concentration.

\subsection{Comminution}

The aim of comminution is to liberate the ore minerals from the gangue by breaking the rock up into smaller particles until there are loose particles of ore mineral (Wills, 1992; Sadrai et al., 2006). Comminution is essentially the size reduction of the fragments of rock/ore (Wills, 1992). Comminution is effected by compression, impact and abrasion, through crushing or grinding/milling. The process usually involves several steps, each comprising a small reduction ratio of three to six. An example of a mineral processing line is demonstrated in Fig. 1. In this example, a vibrating feeder serves the purpose of making coarse separations of mining ores (200 - $800 \mathrm{~mm}$ in diameter) and providing a consistent, even supply of rock material to the jaw crusher. The jaw crusher breaks this material down to a particle size of approximately $10-100 \mathrm{~mm}$. The next stage, the ball mill, is used for grinding various ore and other materials down to particle sizes of around $100 \mu \mathrm{m}$. The stages which follow (classifier to rotary dryer) are used to separate the valuable minerals from the gangue, and are discussed under section 2.2. The physical properties of minerals that have the most influence on the comminution process are hardness, tenacity, cleavage, fracture and common form. 


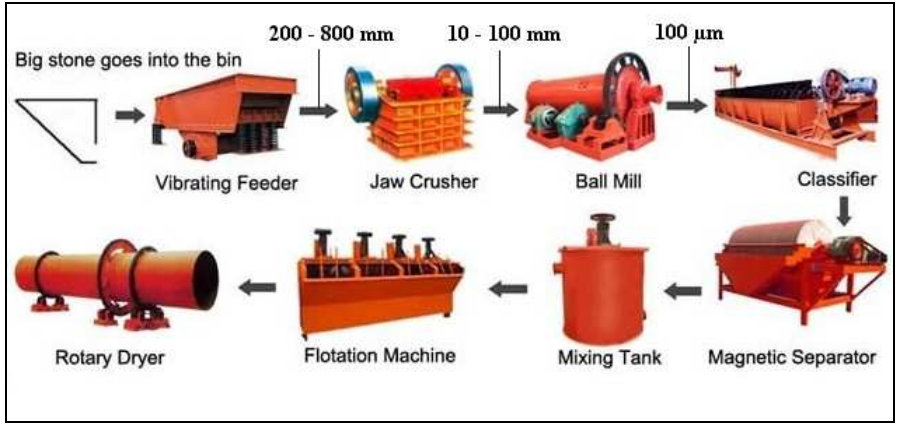

Fig. 1. Mineral processing line (Henan Chuangxin Building-material Equipment Co, 2009)

Hardness is defined as the degree of resistance of a given mineral to scratching, indicating the strength of the bonds that hold the mineral's atoms together (Skinner \& Porter, 1992; Chernicoff \& Fox, 1997; Klein, 2002; Thompson \& Turk, 2007). The hardness of a mineral is tested by scratching the unknown mineral with a series of minerals or substances with known hardness and is one of the most useful diagnostic properties of minerals (Tarbuck \& Lutgens, 1999).

Tenacity is a mineral's physical reaction to stress such as crushing, bending, breaking, or tearing (Klein, 2002). Certain minerals react differently to each type of stress. Since tenacity is composed of several reactions to various stresses, it is possible for a mineral to have more than one form of tenacity. The different forms of tenacity are (Rapp, 2009):

- Brittle - If a mineral is hammered and the result is a powder or small crumbs, it is considered brittle. Brittle minerals leave a fine powder if scratched, which is the way to test a mineral to see if it is brittle. Majority of all minerals are brittle. Minerals that are not brittle may be referred to as non-brittle minerals.

- $\quad$ Sectile - Sectile minerals can be separated with a knife into thin slices, much like wax (e.g. gold).

- Malleable - If a mineral can be flattened out into thin sheets by pounding it with a hammer, it is malleable. All true metals are malleable (e.g. gold).

- Ductile - A mineral that can be stretched into a wire is ductile. All true metals are ductile.

- Flexible but inelastic - Any minerals that can be bent, but remains in the new position after it is bent are flexible but inelastic. If the term flexible is singularly used, it implies flexible but inelastic (e.g. chlorite).

- Flexible and elastic - When flexible and elastic minerals are bent, they spring back to their original position. All fibrous minerals and some acicular and flaky minerals belong in this category (e.g. mica).

Cleavages occur when some crystals break in one or more smooth plane surfaces, whose orientation is determined by the regular atomic structure of the crystal (Klein, 2002; Wenk \& Bulakh, 2004). Certain minerals fracture with an uneven surface when broken, while others split or cleave along distinctive crystallographic planes. Cleavage is thus the ability of a mineral to break, when struck, along preferred directions (Skinner \& Porter, 1992; McGeary et al., 2001). Fig. 2 illustrates seven possible types of mineral cleavage which are: 
- A - One direction of cleavage;

- B - Two directions of cleavage at $90^{\circ}$;

- C - Two directions of cleavage not at $90^{\circ}$;

- D - Three directions of cleavage at $90^{\circ}$;

- $\quad$ E - Three directions of cleavage not at $90^{\circ}$;

- F - Four directions of cleavage; and

- G-Six directions of cleavage.

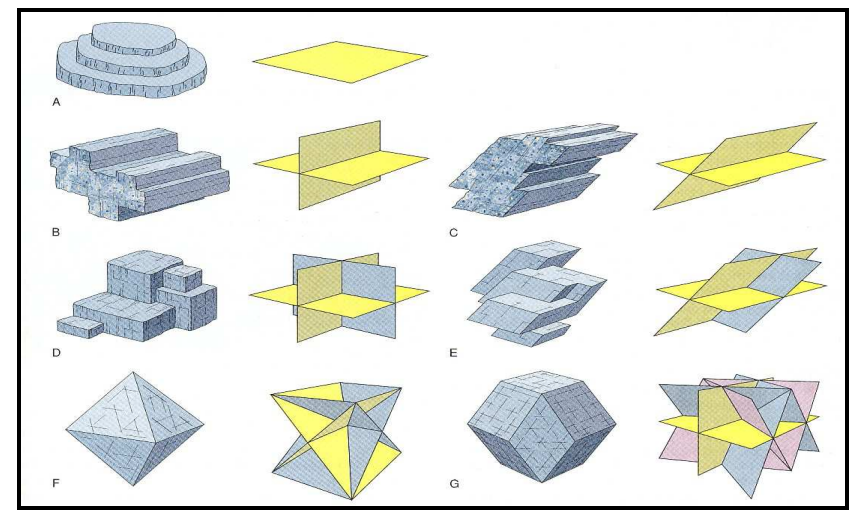

Fig. 2. Seven possible types of mineral cleavage (Wenk \& Bulakh, 2004)

Cleavage is tested by striking or hammering a mineral, and is classified by the number of surfaces it produces and the angles between adjacent surfaces (Chernicoff \& Fox, 1997). A mineral tends to break along certain planes because the bonding between atoms is weaker there. For example, quartz has equally strong bonds in all directions and would thus have no cleavage, whereas micas are easily split apart into sheets due to the fact that the bonding between adjacent atomic sheets is weak. Cleavage is one of the most useful diagnostic tools because it is identical for a given mineral from one sample to another. It is especially useful for identifying minerals when they appear as small grains in rocks (McGeary et al., 2001).

Some minerals have poorly defined cleavages, while others may not even show any at all. When broken, these minerals cause fractures in that they break on generally irregularly oriented curved surfaces, decided more by stress distribution in the crystal at the time of rupture than by the atomic structure of the mineral (Klein, 2002; Wenk \& Bulakh, 2004). Fracture is thus the way a substance breaks when not controlled by cleavage and is the most common type of fracture for minerals (McGeary et al., 2001; Thompson \& Turk, 2007). Fracture may appear as a jagged, irregular or rough surface or as a curved, shell-shaped (conchoidal) surface (Chernicoff \& Fox, 1997).

Minerals may further be identified by their common form. The term form is often used to indicate general outward appearance (Klein, 2002). In crystallography, external shape is denoted by the word habit, whereas the term form is used in a special and restricted sense. Thus a form consists of a group of crystal faces, all of which have the same relation to the elements of symmetry and display the same chemical and physical properties. The term common form is used synonymously to the term habit and refers to the external shape in which a mineral commonly occurs. 


\subsection{Separation}

Automated mineral beneficiation, which essentially involves the separation of specific desired minerals from a crushed/milled mixture of minerals, usually exploits properties such as differences in densities, magnetic susceptibility, electrical conductivity, surface reactivity, refractive index, and fluorescence (Wills, 1992; De Waal, 2007). The most common processes include (Wills, 1992):

- Gravity separation - exploiting the density differences between minerals, and their response to gravity and resistance to motion in a fluid such as water. Typical apparatus includes jigs, Humphries spirals, Reichert cones, sluices, and shaking tables.

- Dense medium separation - exploiting density differences where minerals are introduced to a dense liquid or suspension, in which some minerals will float and others sink, thus effecting separation. A wide variety of separation vessels are employed in industry including some that incorporate a centrifugal aspect to expedite the process.

- Froth flotation - exploiting differences in the surface properties of different types of minerals. Here minerals are exposed to a solution which renders some of the minerals hydrophobic and other hydrophilic. Air is bubbled through the solution in which the minerals are suspended, resulting in separation because the hydrophilic ones settle to the bottom of the solution whereas the hydrophobic minerals can be skimmed off with the soapy froth at the surface.

- Magnetic separation - exploiting the differences in magnetic susceptibility of minerals through use of strong magnetic forces that can be adjusted to separate minerals of differing susceptibility.

- Electrostatic/high tension separation - exploiting differences in electrical conductivity of minerals, in which a charge builds up in non-conductive minerals causing them to stick to charged surfaces, whereas conductive particles do not stick to such surfaces.

Before any of the above separation process can be effective, proper liberation of the ore minerals is essential. Complete liberation is seldom achieved in practice (Wills, 1992; King, 2001), which implies that most particles will comprise both ore and gangue material, with their response to any separation technique being uncertain. The degree of liberation can be described using the following terms:

- A completely liberated particle is one that consists of only one type of mineral, either ore mineral or gangue mineral.

- A middling is a particle that consists of two or more different types of minerals, i.e. it is incompletely liberated.

- Middlings can be further classified into attached mineral (binary, ternary, etc) or enclosed minerals.

- The degree of liberation can also described in terms of what is called particle grade. For example, a liberated particle comprising $100 \%$ ore mineral will have a particle grade of $100 \%$, whereas a middling particle consisting of $25 \%$ ore mineral and $75 \%$ gangue mineral will have a particle grade of $25 \%$.

\section{Rocks used in this research}

Rocks are composed of minerals (Chernicoff \& Fox, 1997) and are called monomineralic when they contain only one mineral (Best \& Christiansen, 2001). Ores are essentially rocks 
that contain one or more type of mineral coveted for its metal content or its physical properties for industrial use (Wills, 1992). The coveted minerals in the ores are called ore minerals (if they contain useful metals) or industrial minerals (if they have useful physical properties). Woollacot and Eric (1994) classify mined material into three categories:

- Mined material consisting of useful rock or soil, where the rock/soil has value in its natural form, e.g. as aggregate or filler material.

- Mined material containing industrial minerals, where the value lies in one or more minerals within the rock that must be liberated and separated from the rock, e.g. diamond in kimberlite, crysotile in greenstones, wollastonite in skarn, etc.

- Mined material containing value-bearing minerals, where the value lies in constituents of one or more minerals within the rock (ore) and the constituent (metal) needs to be extracted from the mineral after the latter has been liberated and separated from the rock (ore), e.g. extraction of copper from copper-bearing minerals such as chalcopyrite $\left(\mathrm{CuFeS}_{2}\right)$ and bornite $\left(\mathrm{Cu}_{5} \mathrm{FeS}_{4}\right)$ occurring as minerals in copper ore.

Rocks may be classified into three groups (see Fig. 3) based on their mode of formation. These are:

- Igneous rocks: formed by the solidification/crystallization of mainly molten silicate material called magma or lava (Chernicoff \& Fox, 1997; Walther, 2005). These rocks consist of tightly interlocked crystals, where the size of the crystals range from $<0.06$ $\mathrm{mm}$ (as in the case of those crystallized from lava at the surface of the earth) to $\pm 10 \mathrm{~mm}$ (as in the case of those crystallized from slow cooling magma deep in the earth's crust). In addition, there are very coarse-grained igneous rocks (pegmatites) which crystallized from magma containing high proportions of volatile material.

- Sedimentary rocks: formed by the solidification of loose material on the earth's surface (Skinner \& Porter, 1992; Chernicoff \& Fox, 1997). The loose material accumulates through the processes of weathering, erosion and deposition/sedimentation. Solidification takes place by a process called lithification/diagenesis, which involves the compaction, cementation and recrystallisation of sediments that are deeply buried $( \pm 3 \mathrm{~km})$. Sedimentary rocks are also formed by the lithification of chemical precipitates that accumulate as layers of microcrystals on lake floors or subterranean cavities (Thompson \& Turk, 2007; Carlson et al., 2008).

- Metamorphic rocks: formed by the exposure of rocks to high temperature and/or pressures during magmatic and/or tectonic events (Chernicoff \& Fox, 1997). Heat from nearby magmatic intrusions and pressure induced by mountain-building and other tectonic processes causes reactions and recrystallisation of minerals resulting in new sets of minerals within metamorphosed rocks. The process of recrystallisation occurs in the solid state, or in extreme cases, in a partially molten state.

The three rock groups are characterised by important differences in the types of minerals and their textural relationships. These differences are manifest in the physical properties of the rocks, such as strength and elasticity ratios, that affect their behaviour during comminution. Consequently, the physical properties of minerals are not the only controlling factors on the effectiveness of comminution, but more importantly, the mineral assemblage and texture of the rock, which is the reason why three different rocks have been selected for trial in this research (dolerite, sandstone and marble - see Table 1 for selected characteristics of these 
rocks). The same is true for different types of ores where the textures ultimately determine the grain-size to which an ore needs to be milled before liberation is properly effected.

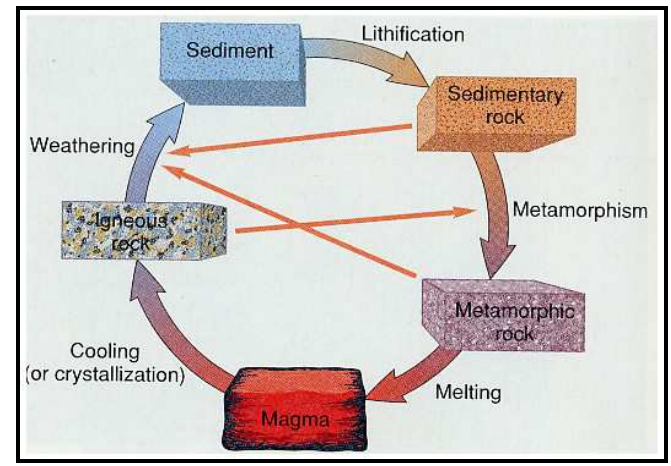

Fig. 3. The rock cycle (Chernicoff \& Fox, 1997)

Dolerite is an igneous intrusive rock with medium-sized grains (Aloian, 2010), which was injected as a fluid into older water-laid sedimentary rocks (Leaman, 1973). It was injected under pressure head of at least $700 \mathrm{~kg} / \mathrm{cm}^{2}$ and caused severe disruptions of pre-existing geological features. As the initially hot fluid was forced into cold sediments, severe thermal gradients were produced during the period of injection and cooling. Dolerite is primarily composed of two essential minerals, termed plagioclase and pyroxene. The mineralogy of dolerite is closely related to the form of the intrusion and the thermal history.

Sandstones are types of sedimentary rocks, which consist particularly of mineral grains, deposited in parallel layers, which have subsequently been cemented together. Sandstones are mostly white, light grey, buff, reddish or yellowish brown in colour. Quartz is the predominant mineral found in most sandstones being chemically stable and physically durable under most weathering and transporting processes (Evans, 1972; Dietrich \& Skinner, 1979). Sedimentary rocks formed by the deposition of mineral grains are classified on the basis of grain-size. Sandstones have grain-sizes ranging from $0.0625 \mathrm{~mm}$ to $2 \mathrm{~mm}$ and generally comprise quartz with or without feldspar and other mineral fragments. In addition, sandstones may also have interstitial finer-grained material such as clay or cementing material which can vary in amount as a percentage of the total rock $(<5-25 \%)$ (McGeary et al., 2001).

Marble is an example of a metamorphic rock consisting primarily of calcite and/or dolomite. Marble may be snow white, grey, black, buff, yellowish, chocolate, pink, mahogany-red, bluish, lavender or greenish in colour. The grains within marble tend to be of a rather uniform size (Dietrich \& Skinner, 1979). Marble forms by the metamorphism of limestone, during which recrystallisation of calcite occurs (Evans, 1972). Completely recrystallised limestone can result in a rock with interlocking calcite crystals and the obliteration of the stratification and other textural characteristics of the parent limestone. Impure parent limestone produces marble that contains other minerals in addition to calcite, with the most common being quartz, anorthite, serpentine, tremolite, diopside, and forsterite. The minerals present depend on the nature of the impurities and the grade of metamorphism. 


\begin{tabular}{|c|c|c|c|}
\hline Characteristic & Dolerite & Sandstone & Marble \\
\hline Rock type & Igneous (hypabysal) & Sedimentary & Metamorphic \\
\hline Texture & $\begin{array}{l}\text { Medium grained and } \\
\text { smooth }\end{array}$ & $\begin{array}{l}\text { Medium grained and } \\
\text { rough }\end{array}$ & Coarse grained \\
\hline Principal minerals & $\begin{array}{l}\text { Plagioclase and } \\
\text { Pyroxene }\end{array}$ & Quartz & Calcite and dolomite \\
\hline $\begin{array}{c}\text { Principal mineral } \\
\text { hardness }\end{array}$ & $\begin{array}{l}\text { Plagioclase: } 6 ; \\
\text { Pyroxene: } 6\end{array}$ & 7 & 3 \\
\hline $\begin{array}{c}\text { Principal mineral } \\
\text { breakage }\end{array}$ & $\begin{array}{l}\text { Two good cleavages at } \\
\qquad 90^{\circ}\end{array}$ & Fracture & $\begin{array}{c}\text { Three good cleavages } \\
\text { at } 75^{\circ} / 105^{\circ}\end{array}$ \\
\hline Specific gravity & $3.00-3.05$ & $2.00-2.60$ & $2.6-2.86$ \\
\hline Resistivity ( $\Omega . \mathrm{m})$ & $20-200$ & $8-4000$ & $100-250000000$ \\
\hline Colour & $\begin{array}{c}\text { Dark bluish, weathers } \\
\text { to brown }\end{array}$ & $\begin{array}{l}\text { White, light grey, buff, } \\
\text { reddish or yellowish } \\
\text { brown }\end{array}$ & $\begin{array}{l}\text { White, grey, black, } \\
\text { buff, yellowish, } \\
\text { chocolate, pink, } \\
\text { mahogany-red, bluish, } \\
\text { lavender or greenish }\end{array}$ \\
\hline Porosity & $0.1-0.5 \%$ & $5.0-25.0 \%$ & $0.5-2.0 \%$ \\
\hline
\end{tabular}

Table 1. Selected characteristics of dolerite, sandstone and marble

The rocks discussed above were selected for this research and were labelled with the text JS (representing James Swart) followed by an alphabetical label as shown in Table 2. This was done to prevent confusion between the different samples which were treated with electrical RF power.

\begin{tabular}{|c|c|c|}
\hline Sample code & Rock family & Rock type \\
\hline JSA & Igneous & Dolerite \\
\hline JSB & Metamorphic & Marble \\
\hline JSD & Sedimentary & Sandstone \\
\hline
\end{tabular}

Table 2. Rock samples chosen for this research

\section{Electrical treatment techniques}

Electrical treatment techniques refer to the use of electrical energy in specific ways to achieve desired changes in certain solid and liquid materials. Four specific electrical techniques currently employed include:

- Microwave pre-treatment;

- Ultrasound pre-treatment;

- High voltage electrical pulses; and

- Radio-frequency power. 


\subsection{Microwave pre-treatment}

Numerous studies have shown that microwave pre-treatment is beneficial for:

- Drying of raisins (Kostaropoulos \& Saravacos, 1995);

- Accelerating enzymatic hydrolysis of chitin (Roy et al., 2003);

- Improved grindability and gold liberation (Amankwah et al., 2005);

- Improving the moisture diffusion coefficient of wood (Li et al., 2005);

- Enhancement of phosphorus release from dairy manure (Pan et al., 2006);

- Strength reduction in ore samples (Jones et al., 2007);

- $\quad$ Enhancing enzymatic digestibility of switchgrass (Hu \& Wen, 2008);

- A higher extractive yield of vegetable oil from Chilean hazelnuts (Uquiche et al., 2008); and

- $\quad$ The liberation of copper carbonatite ore after milling (Scott et al., 2008).

Microwave pre-treatment is found in many other applications where microwaves induce transient motions of free or bound charges, such as electrons or ions or charge complexes such as permanent dipoles. The resistance to these motions causes losses, which result in attenuation of the electric field and increased dissipation of energy in the material (Amankwah et al., 2005).

The most important early work on microwave pre-treatment was that of Chen et al. (1984), who investigated the reaction of 40 minerals to microwave exposure in a waveguide applicator which allowed the mineral samples to be inserted in an area of known high electric field strength. This study showed that microwave heating is dependent on the composition of the minerals.

Walkiewicz et al. (1988) later published data on microwave heating of a number of minerals and speculated on the potential reduction in grinding energy required for minerals with stress fractures induced by microwave heating. Kingman et al. (2004) published an article stating that for the first time microwave-assisted comminution may have the potential to become economically viable. This conclusion was based on significant reductions in strength, coupled with major improvements in liberation of valuable minerals.

The microwave heating system is made up of four basic components: power supply, magnetron, cavity for the heating of the target material and waveguide for transporting microwaves from the generator to the cavity. Commonly, an industrial size microwave heating system is set to a frequency of $915 \mathrm{MHz}$ with a magnetron as high as $75 \mathrm{~kW}$ power and an average working life of 6000 hours (Smith, 1993).

Microwave heating is a sophisticated electroheat technology requiring specialist knowledge and expensive equipment if meaningful results are to be obtained (Bradshaw et al., 1998). Included in this is the precision involved in the design and construction of the magnetron and cavity.

\subsection{Ultrasound pre-treatment}

The use of ultrasound pre-treatment has been applied to:

- Accelerate the anaerobic digestion of sewage sludge (Tiehm et al., 1997); 
- Comminution (Gaete-Garretón et al., 2000);

- Titanium tanning of leather (Peng et al., 2007);

- Ammonia steeped switchgrass for enzymatic hydrolysis (Montalbo-Lomboy et al., 2007);

- $\quad$ Two-Minute skin anaesthesia (Spierings et al., 2008); and

- Cassava chip slurry to enhance sugar release for subsequent ethanol production (Nitayavardhana et al., 2008).

The feasibility of the application of ultrasound energy to the grinding process as a viable avenue of study was stated at a meeting of the International Comminution Research Association in Warsaw, 1993 (Gaete-Garretón et al., 2000). One of the most significant reasons for this proposition originated in the accepted fact that inside any material there are a number of inherent cracks and ultrasonic energy has the capacity to produce crack propagation from within the particle to its outer surface, in spite of the very low energy producing an efficient fracture. An ultrasonic grinding machine can be designed in the form of a roller mill constructed over a specially designed ultrasonic transducer (Gaete-Garretón et al., 2003).

Gärtner (1953) was probably the first researcher to have attempted using ultrasonic waves in the fragmentation of particles, obtaining poor results. Leach and Rubin (1988) studied the fragmentation of resonant rocks samples fixed to the tip of an ultrasonic transducer, observing a preferred fracture at the nodes. Yerkovic et al. (1993) made grinding tests comparing standard copper ore with ultrasonic pre-treated samples in a ball mill. The pretreated ore exhibited a $32 \%$ higher grinding rate.

An active roll, which is itself an ultrasonic transducer, is located in front of a passive roll. The vibration in extensional mode combines compression and shear action of the active roll on the mill feed. A funnel feeds the material into the gap by gravity which are then nipped by the rolls. A spring system furnishes the stress applied to the ore and the stress level can be varied by adjusting the spring tension. The rotation of the roll is produced by a variable speed electric motor. The ground ore is collected under the rolls in an iron receiver fed by gravity.

It is evident from the above description of the ultrasound mill that many different parts have to work together in the application of an ultrasonic field in the stressing zone of the material. This setup proves to be very precise and time consuming.

\subsection{High voltage pulsed power}

High voltage pulsed power has been applied to:

- Enhance coal comminution and beneficiation (Touryan \& Benze, 1991);

- Mineral liberation (Andres et al., 2001);

- $\quad$ Metal peening (Zhang \& Yao, 2002);

- $\quad$ Rock fragmentation (Cho et al., 2006);

- Recover ferrous and non-ferrous metals from slag waste (Wilson et al., 2006); and

- Convective drying of raisins (Dev et al., 2008).

The history of high voltage pulsed power can be traced back to 1752 when Benjamin Franklin discovered that lightning was a discharge of static electricity (Staszewski, 2010). It 
was reported that he raised a kite (with a key attached to his end of the string) which was tied to a post with a silk thread. As time passed, Franklin noticed the loose fibres on the string stretching out; he then brought his hand close to the key and a spark jumped the gap. This electrical discharge across a gap would prove significant in the research of high voltage pulsed power techniques.

In 1924 Erwin Marx described an apparatus, which produced high voltage pulses, and became known as the Marx-Generator (Fontana, 2004). It is a clever technique for generating high-voltage short-duration waveforms by charging a number of capacitors in parallel, then quickly discharging them in series. While originally based upon the use of air-dielectric spark gaps to provide the switching mechanism, solid-state variants utilizing avalanche diodes or other solid-state switching devices have been used to generate nanosecond duration pulses having amplitudes exceeding several thousand volts of direct current (Baker \& Johnson, 1993).

There has been intense interest for the last several decades in the use of high-voltage pulse technology for rocks disintegration (Cho et al., 2006). The methods of electric pulse disintegration are mainly electrohydraulics and internal breakdown inside bulk solid dielectrics (Owada et al., 2003). The first method refers to the generation of an intense shock wave in water from the passage of electrical current through water and the crushing and subsequent constituent separation by the impact of that shock wave on the sample. The second method refers to the passage of electrical current through the rock and the separation of the mineral contents from the rock matrix by preferential current flow along the mineral/rock boundary interface. Rock disintegration using the second method consumes substantially less energy than that using the first method and enhanced effect of liberation of mineral constituents of rock aggregates.

A major limiting factor to spark-gap switches used in high voltage pulsed power applications was their short lifetime (Winands et al., 2005). Other shortcomings with spark gaps are related to their limited pulse repetition rate, strong electrode erosion, insulator degradation, high arc inductance, limited hold-off voltage, and costly triggering.

\subsection{Radio-frequency power}

The application of electrical energy in the RF heating of various materials has been successfully employed in the following:

- Electrical heating along with RF heating was used in the 1970s for the recovery of bitumen from tar sand deposits (Kawala \& Atamanczuk, 1998);

- $\quad$ RF treatments can potentially provide an effective and rapid quarantine security protocol against codling moth larvae in walnuts as an alternative to methyl bromide fumigation (Wang et al., 2001);

- $\quad$ RF heating was successfully used to increase the temperature of human blood without incurring cell destruction (Pienaar, 2002);

- Treating fruit in immersion water of selected salt concentration and RF power may be used to develop an effective alternative quarantine method for fruit (Ikediala et al., 2002);

- $\quad$ RF power in conjunction with conventional hot water treatment can be used to develop feasible heat treatments to combat codling moths in apples (Wang et al., 2006); 
- RF-based dielectric heating was used in the alkali pre-treatment of switchgrass to enhance its enzymatic digestibility (Hu et al., 2008); and

- Dielectric heating of soil using radio waves (RW) can be applied to support various remediation techniques, namely biodegradation and soil vapor extraction, under in situ or ex situ conditions (Roland et al., 2008).

Dielectrics have two important properties (Jones et al., 2002):

- They have very few free charge carriers. There is very little charge carried through the material matrix when an external electrical field is applied.

- The molecules or atoms comprising the dielectric exhibit a dipole movement.

The principle of dielectric heating basically involves the absorption of energy by dipoles (Chee et al., 2005). A dipole is essentially two equal and opposite charges separated by a finite distance. An example of this is the stereochemistry of covalent bonds in a water molecule, giving the water molecule a dipole movement. Water is the typical case of a nonsymmetric molecule. Dipoles may be a natural feature of the dielectric or they may be induced (Kelly \& Rowson, 1995). Distortion of the electron cloud around non-polar molecules or atoms through the presence of an external electric field can induce a temporary dipole movement. This movement generates friction inside the dielectric and the power is dissipated subsequently as heat. The interaction of dielectric materials with electromagnetic radiation in a given frequency band results in energy absorbance (Wang et al., 2001; Jones et al., 2002). The power coupled into a sample is nearly constant when the electric field intensity and dielectric loss factor do not vary at a given frequency. The heat generated per unit volume $\left(P\right.$ in $\left.\mathrm{W} / \mathrm{m}^{3}\right)$ in a dielectric material when exposed to RF power can be expressed as (Nelson, 1996):

$$
\mathrm{P}=5.56 \times 10^{-11} \times \mathrm{f} \times \mathrm{E}^{2} \times \varepsilon \quad \mathrm{W} / \mathrm{m}^{3}
$$

Where

$f \equiv$ frequency of radiation in $\operatorname{Hertz}(\mathrm{Hz})$

$E \equiv$ the electric field intensity in Voltage per meter $(\mathrm{V} / \mathrm{m})$

$\varepsilon \equiv$ the permittivity of the material

Moreover, the amount of heat $(Q)$ required to change the temperature of a given material is proportional to the mass of the material and to the temperature change as given by Giancoli (2005):

$$
\mathrm{Q}=\mathrm{C} \times \mathrm{m} \times \Delta \mathrm{T} \quad \mathrm{J}
$$

Where

$\Delta T \equiv$ temperature change in degrees Celsius $\left({ }^{\circ} \mathrm{C}\right)$

$m \equiv$ the sample mass in kilogram $(\mathrm{kg})$

$\mathrm{C} \equiv$ specific heat capacity in Joules per kilogram per degrees Celsius $\left(\mathrm{J} / \mathrm{kg} /{ }^{\circ} \mathrm{C}\right)$

Subsequently, temperature rise within the sample due to absorbed electromagnetic energy is really a function of the heating time. The temperature increase can be estimated by assuming that the electric field is uniform and the dielectric properties are relatively 
constant. The temperature increase $\left(\Delta T\right.$ in $\left.{ }^{\circ} \mathrm{C}\right)$ of the sample during RF heating can furthermore be expressed as (Halverson et al., 1996):

$$
\Delta \mathrm{T}=\frac{\mathrm{k} \times \mathrm{P}}{\mathrm{C} \times \mathrm{m}} \times \Delta \mathrm{t} \quad{ }^{\circ} \mathrm{C}
$$

Where

$\mathrm{k} \equiv$ coupling coefficient

$P \equiv$ input power $(\mathrm{W})$

$\Delta t \equiv \mathrm{RF}$ heating time in seconds (s)

The practical setup used to achieve the transfer of RF power to a dielectric sample is shown in Fig. 4, and consists of a transformer, rectifier, oscillator, an inductancecapacitance pair commonly referred to as the 'tank circuit', and the work circuit (Wang et al., 2001). The transformer raises the voltage to $9 \mathrm{kV}$ and the rectifier provides a direct current which is then converted by the oscillator into RF power at $27 \mathrm{MHz}$. This frequency is determined by the values of the inductance and capacitor in the tank circuit. The parallel-plate electrodes, with sample in-between, act as the capacitor in the work circuit. The gap of the electrode plates can be changed to adjust RF power coupled to the sample between the two plates.

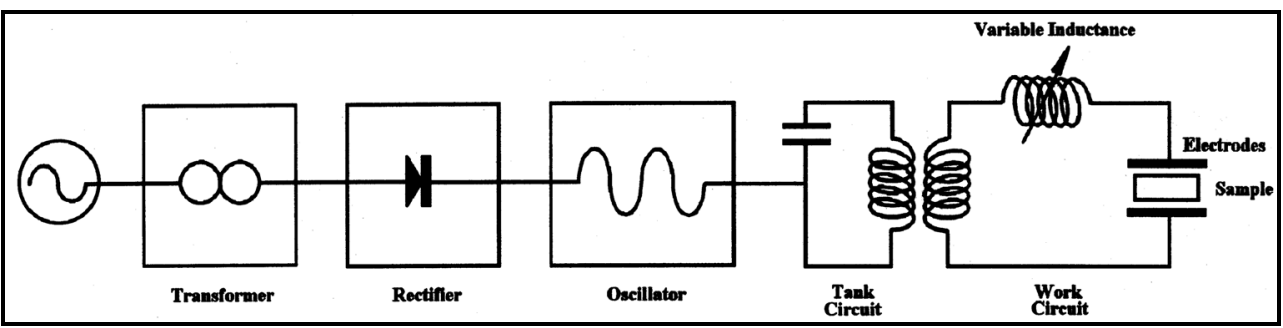

Fig. 4. Practical setup used in the dielectric heating of a material (Wang et al., 2001)

Three (microwave, ultrasound and high voltage pulsed power) of the four electrical treatment techniques noted above have been successful in weakening the mineral grain boundaries of rocks, thereby enhancing mineral liberation within the rock comminution process. This is accomplished by the generation of stress within the material, which gives rise to fractures and breakages. The weakening of mineral grain boundaries may yet be achieved by using RF power.

\section{Proposed new treatment: RF power}

Emanating from the above scientific literature on the use of electrical energy in various treatment techniques, the following hypotheses are made:

- The successful transfer of RF power to specific rocks through dielectric heating may exhibit positive effects on the textural characteristics of these samples; and

- These textural changes may further contribute to enhancing the rock comminution process, thereby increasing the percentage of valuable liberated minerals. 
As far as could be established, no current literature exists substantiating these hypotheses. A novel electrical treatment technique of rock samples involving RF power within the veryhigh frequency (VHF) range $(30-300 \mathrm{MHz})$ is subsequently presented.

A high power RF amplifier may be connected to a rock sample (acting as a dielectric material) by means of a suitable coupling device. RF power is transferred from the amplifier to the rock sample at the resonating frequency. Confirmation of power transfer may be determined through the following results:

- Temperature increase on the surface of the rock sample;

- $\quad$ Surface colour change of the sample;

- Screening of particles from pre-treated and non-treated sample;

- Scanning electron microscope (SEM) analysis of pre-treated and non-treated samples; and

- $\quad$ Power consumption analysis of pre-treated and non-treated samples in a ball mill.

The practical setup of this experiment is shown in Fig. 5. A commercial RF transceiver (ICOM IC-V8000) may be used in conjunction with two RF amplifiers (MIRAGE PAC30$130 \mathrm{~B})$ to generate the power required at the resonating frequency. However, the output impedance of the RF amplifiers is $50 \Omega$ while the input impedance of the rock samples may vary dramatically from a few hundred ohm to a few thousand ohm (determined by a practical setup discussed by Swart et al. (2005)).This necessitates the use of a matching network and a coupling device, which are presented next.

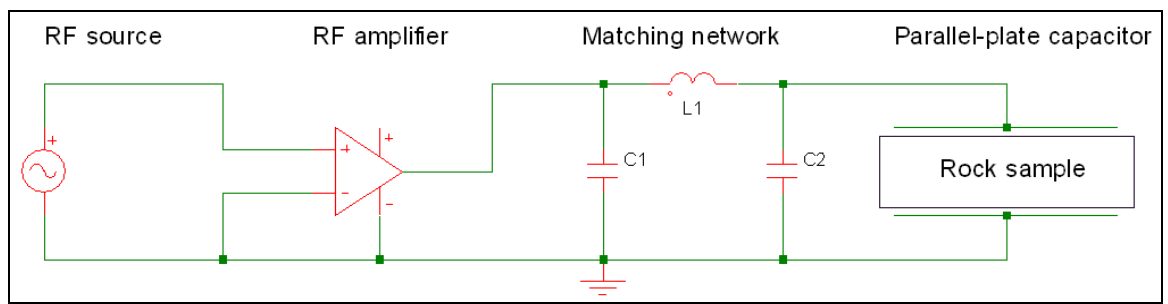

Fig. 5. Practical setup of the experiment based on research by Wang et al. (2001)

\section{Innovative coupling technique}

Two RF measurement coupling techniques currently exist for connecting RF equipment to dielectric materials, namely the cylindrical capacitor with coaxial electrodes and the parallelplate capacitor (PPC) with disk electrodes.

Numerous articles list the usefulness of the cylindrical capacitor in measuring electrical impedances (Levitskaya \& Sternberg, 2000; Bagdassarov \& Slutskii, 2003; Azimi \& Golnabi, 2009). A cylindrical capacitor consists of a three-part coaxial capacitance sensor in which the middle one acts as the main sensing probe (Azimi \& Golnabi, 2009). The outer conductor is considered to be a guard ring in order to reduce stray capacitance and error measurements. Aluminium material is often used for manufacturing the capacitor tube electrodes (Rutschlin et al., 2006). The cylindrical capacitor extends the frequency limit of measurements to $1 \mathrm{GHz}$ for materials with a dielectric permittivity of less than 25 (Levitskaya \& Sternberg, 2000). However, cutting a sample of marble (dielectric permittivity 
of 8) into a cylindrical form with exact diameter spacing proves cumbersome and difficult in the absence of a core-drill. For this reason the PPC was reviewed as a coupling device.

A PPC with disk electrodes is formed when a dielectric material or sample is sandwiched between two conducting plates (see Fig. 6). These conducting plates (made from copper due to its good conductivity (Zaghloul, 2008) are connected to relevant test equipment via standard RF connectors and coaxial cables. Swart et al. (2009) suggests that high frequency measurements (up to $950 \mathrm{MHz}$ ) using PPCs are easier on dielectric material samples with small widths $(<5 \mathrm{~mm})$ and low dielectric permittivities (around 8). Subsequently, all rock samples were cut to a width of $4 \mathrm{~mm}$ (using a laboratory rock cutter) and sandwiched within a PPC connected to a matching network housed in a novel wooden jig.

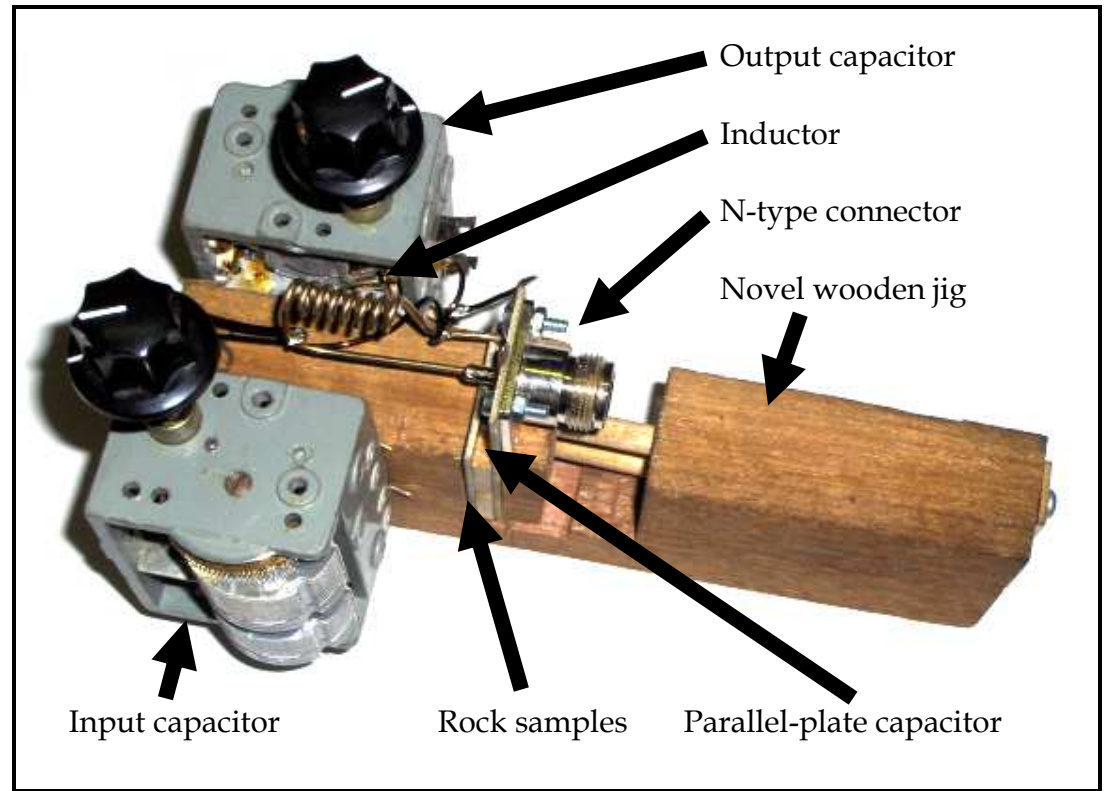

Fig. 6. Two rock samples inside a PPC with the matching network

The matching network ensures maximum power transfer to the rock samples and was made from mechanical plate trimmer capacitors (5-100 pf) and an inductor constructed from silver wire (silver solder). Silver has a lower resistivity $\left(1.624 \times 10^{-8} \Omega-\mathrm{cm}\right)$ than that of copper $\left(1.728 \times 10^{-8} \Omega-\mathrm{cm}\right)$ at $20^{\circ} \mathrm{C}$ and is therefore a better conductor with less attenuation (Hutchinson, 2001). Hence, it will not heat up as quickly as copper will, which could weaken the soldering joints. Pozar (2005) substantiates this claim by noting that the conductivity of silver $\left(6.173 \times 10^{7} \mathrm{~S} / \mathrm{m}\right.$ at $\left.20^{\circ} \mathrm{C}\right)$ is higher than that of copper $\left(5.813 \times 10^{7} \mathrm{~S} / \mathrm{m}\right.$ at $\left.20^{\circ} \mathrm{C}\right)$.

\section{Practical setup of the equipment}

The matching network's performance was evaluated using two RF amplifiers (MIRAGE PAC30-130B) driven by a commercial RF transceiver (ICOM IC-V8000). The RF transceiver generated a $3.2 \mathrm{~W}$ RF signal which was amplified by the first RF amplifier to approximately 
$32 \mathrm{~W}$, and in turn, to approximately $113 \mathrm{~W}$ by the second RF amplifier. This was necessary because the RF transceiver was not capable of providing more than $70 \mathrm{~W}$ of RF power. The input to the RF amplifiers was limited to $35 \mathrm{~W}$ to ensure correct operation of the driver stages. The practical setup is shown in Fig. 7.

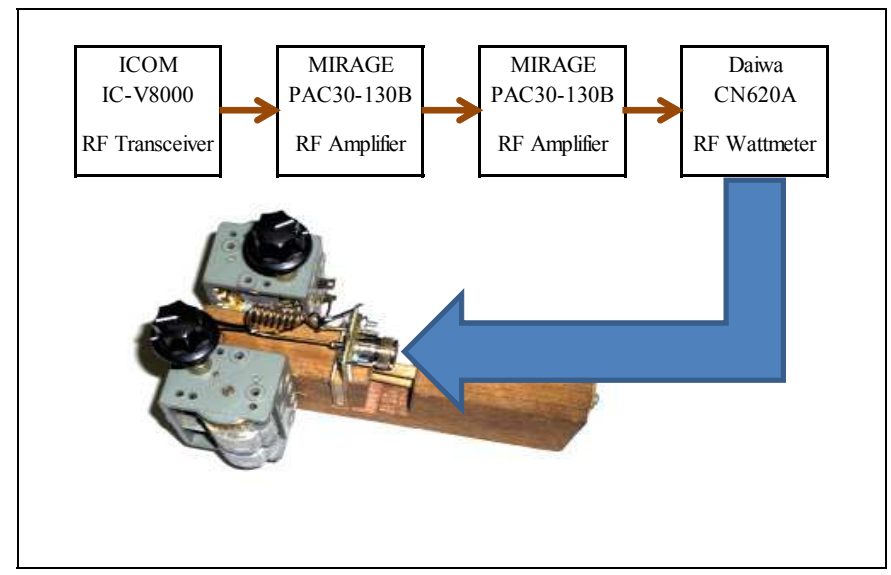

Fig. 7. Practical setup to determine the efficacy of the matching network

The output of the RF transceiver was first connected straight to the matching network through a RF wattmeter to determine the standing wave ratio (SWR) of the circuit. The reason for this is to ensure that the SWR value remain as close as possible to one, in order to prevent an excess of reflected power damaging the output stage of the RF amplifier. With the two RF amplifiers bypassed, the RF transceiver was activated (keyed) to generate a 3.2 $\mathrm{W}$ signal at $160 \mathrm{MHz}$ (approximate centre of the VHF range which extends from $30-300$ $\mathrm{MHz}$ ). The trimmer capacitors were then fine-tuned to obtain the lowest possible SWR. The RF amplifiers were then switched on (thus connecting the amplifiers directly into the circuit between the RF transceiver and the matching network). The RF transceiver was keyed again and approximately $113 \mathrm{~W}$ of forward power was measured with the wattmeter. Two different wattmeters were used to verify the reliability of the measurements. The reflected power measured approximately $1.8 \mathrm{~W}$ resulting in a SWR reading of 1.308 . The successful transfer of RF power $(82 \mathrm{~W})$ to the rock samples was further collaborated by a significant rise in surface temperature, as described in the following results section.

\section{Results of treating rock sample with RF power}

Rock samples of specific size which have been exposed to a known amount of RF power at a given frequency are referred to as treated samples, while those which were not exposed are termed untreated samples. Possible changes that were considered include textural, phase, grindability, colour, temperature and electrical property changes. Textural changes (changes in grain size and inter-grain boundary relationships) were considered using polarizing optical microscopy on polished thin sections of the rock samples. Geological type samples are often cut into thin slices, using diamond type saws, and then fixed onto glass slides using a strong adhesive (Tiedt \& Pretorius, 2002). The mount is then polished, and subsequently coated with a conductive layer. These thin sections were also used to determine phase changes (changes in 
Evaluating the Effects of Radio-Frequency

Treatment on Rock Samples: Implications for Rock Comminution

mineral assemblage) using polarizing optical microscopy. The textural and phase changes were analyzed with a Phillips model XL30 DX41 scanning electron microscope. Grindability, being the changes in the power consumption during grinding and changes in the particle size distribution after grinding, was determined by measuring the power consumption during milling (using a HIOKI 3286-20 clamp on power meter) and by performing particle size analyses (sieve tests of screen sizes $250 \mu \mathrm{m}, 150 \mu \mathrm{m}, 90 \mu \mathrm{m}$ and $38 \mu \mathrm{m}$ ). Surface colour changes were visually observed while surface temperature changes were measured (using a LUTRON TM-2000 digital thermometer and K-type thermocouples pressed firmly against the surface of the rock samples). Contrasts between the electrical properties (resonating frequencies and impedances obtained from a HP $8752 \mathrm{C}$ network analyzer) of the untreated and treated samples are further indicated. The results from the above considerations were interpreted in terms of the mineralogical and chemical composition of the samples.

\subsection{SEM analysis of photomicrographs}

A comparison of the photomicrographs of the untreated and treated rock samples reveals no significant differences in grain size, grain shape, minerals present or inter-granular textures. No visible cracks or fractures exist along the mineral grain boundaries of the treated rock samples, as shown in Fig. 8 - 10.
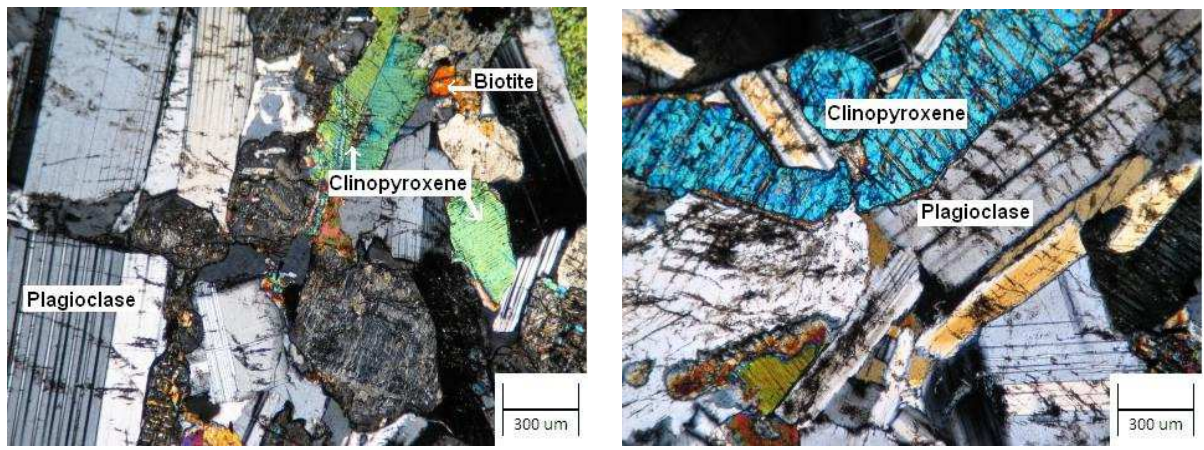

Fig. 8. Photomicrographs of the untreated (left) and treated (right) JSA rock sample taken under cross-polarized light
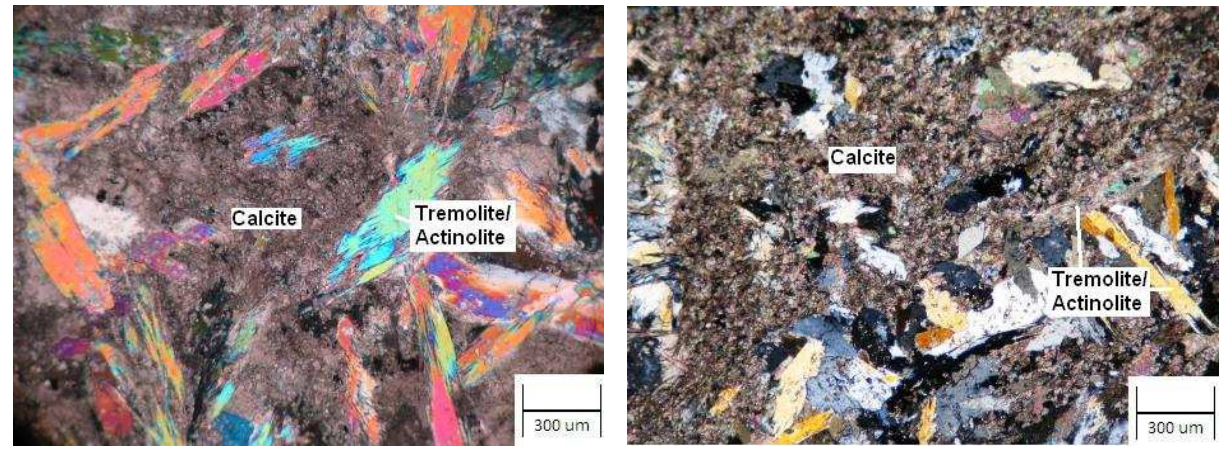

Fig. 9. Photomicrographs of the untreated (left) and treated (right) JSB rock sample taken under cross-polarized light 

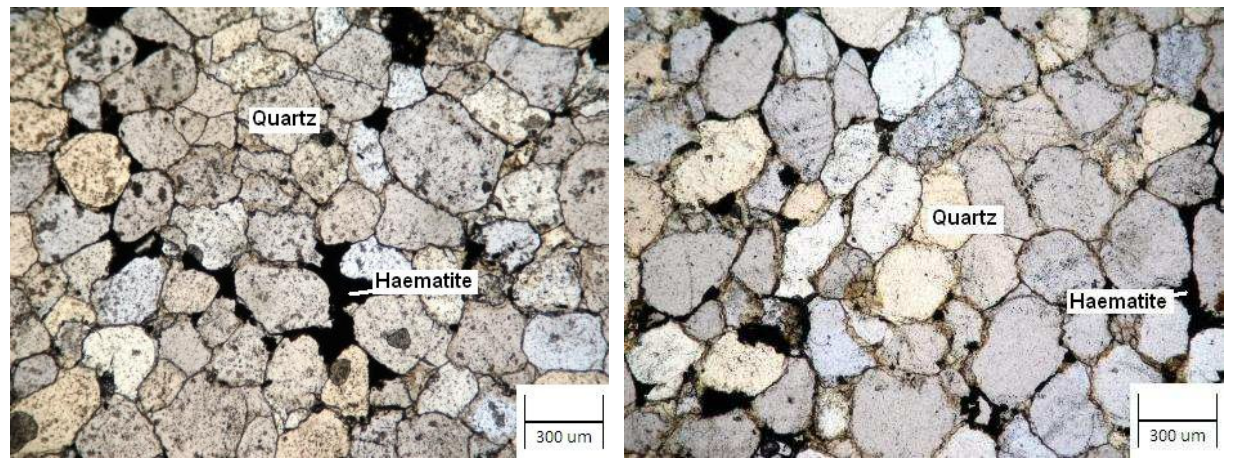

Fig. 10. Photomicrographs of the untreated (left) and treated (right) JSD rock sample taken under plane-polarized light

\subsection{Particle screen analysis}

Determination of the relative grindability of the untreated and treated samples was done by measuring the power consumption during grinding and comparing the particle size distribution after the grinding process. The untreated and treated samples were ground down to powder form in a laboratory swing mill, which consists of a shallow cylinder; two internal rings and a heavy disc. These mills are designed for reduction of materials to extremely fine powders for preparation of samples for spectra analysis. All samples were milled for 2 minutes with corresponding power measurements taken of the power consumed. A small brush was used to clean out the grounded samples (in the form of powder or dust) from the pot, which were then weighed with a digital scale.

The powder samples were next transferred to particle screening sieves $(250 \mu \mathrm{m}, 150 \mu \mathrm{m}, 90$ $\mu \mathrm{m}$ and $38 \mu \mathrm{m}$ screens placed on top of each other). This screen combination was placed in an ENDECOTTS EFL2000 shaker for 5 minutes. Rock sample particles left behind in each screen was weighed individually. These weightings were converted into percentages by dividing each weighting by the total mass and cumulative mass percentages by adding successive mass percentages. The results of this evaluation are shown in Fig. 11 - 13, where the untreated samples are shown by means of a triangle or cross. The treated samples are indicated by means of a diamond or square. The left sketch indicates the particle size distribution to cumulative mass, while the right hand sketch shows the frequency of occurrence for each grain size. Four samples were used in the analysis of the JSA and JSD rock samples, to ensure repeatability and reliability of the results. Three JSB rock samples were used in this analysis, as it showed little or no variation in post-grinding particle size distribution between the untreated and treated rock samples.

However, JSA and JSD revealed minor to major variations. The treated JSA sample (right hand graph) shows a significant coarser grain size distribution with a mode value of $90 \mu \mathrm{m}$, whereas it is $38 \mu \mathrm{m}$ for the untreated samples. Similarly, the $\mathrm{d}_{80}$ (nominal sieve size allowing $80 \%$ of the powered sample to pass through - left hand gragh) is approximately $85 \mu \mathrm{m}$ for the treated ones, but less than $38 \mu \mathrm{m}$ for the untreated samples. This means that for the same amount of grinding ( 2 minutes) the treated samples were reduced in size to a lesser extent than the untreated samples, suggesting reduced grindability. This may also indicate that 
fewer fines (smaller particles) are generated and therefore over-grinding is reduced. A similar situation is evident for the JSD sample, which is a sandstone with granular textures in which sand grains are cemented with matrix material such as haematite, whereas the JSA sample has a typical igneous texture of interlocking crystals.
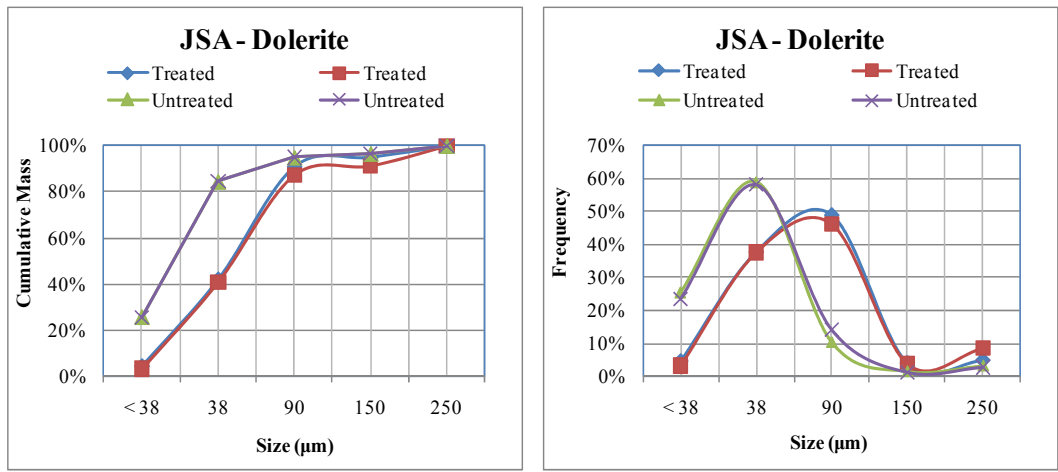

Fig. 11. Particle screen results for the untreated and treated JSA sample
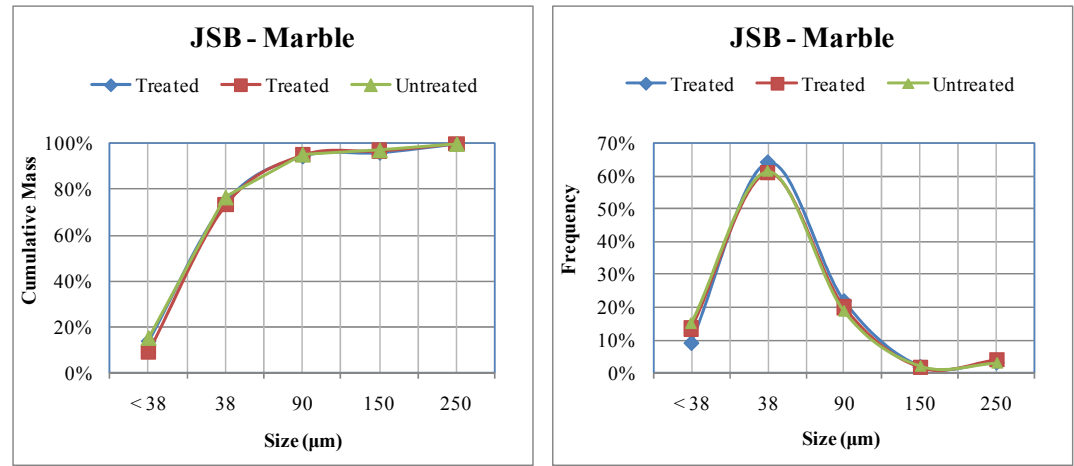

Fig. 12. Particle screen results for the untreated and treated JSB sample
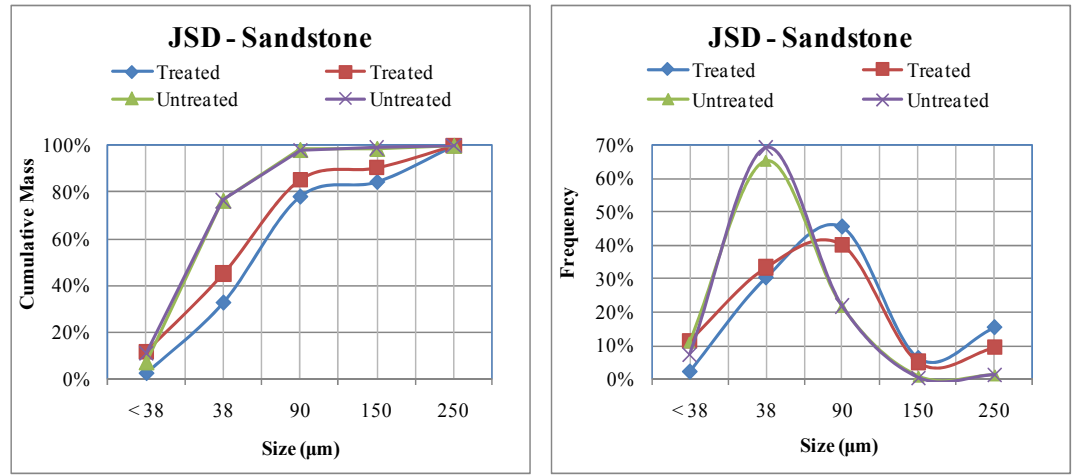

Fig. 13. Particle screen results for the untreated and treated JSD sample 
Polished sections of the powdered samples were obtained to check for textural changes with regard to particle sizes of the untreated and treated samples (see Fig. 14 -16). The size of the mineral grains is indicated, revealing no significant reduction in size between the untreated and treated samples.

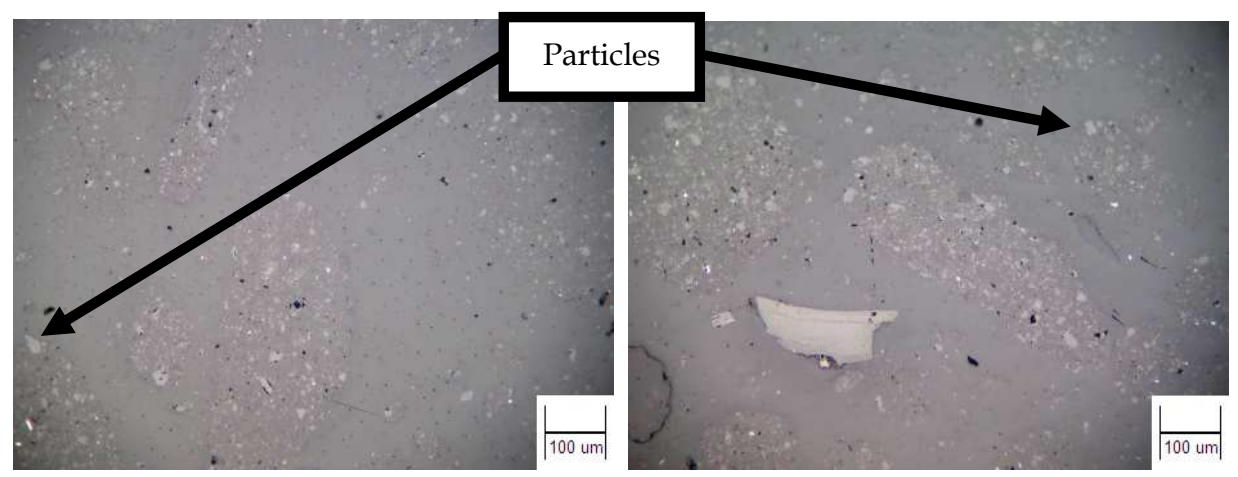

Fig. 14. Photomicrographs of the untreated (left) and treated (right) JSA sample

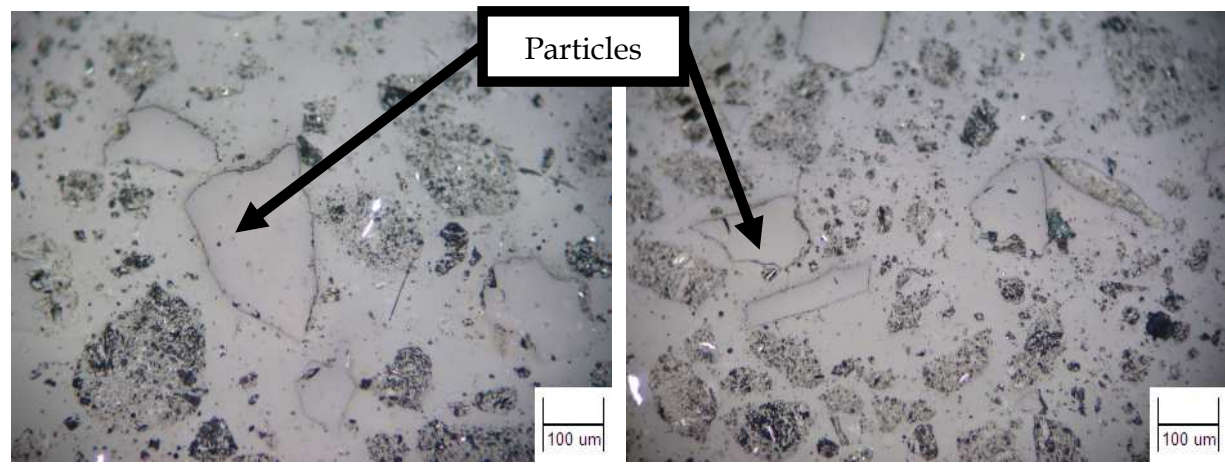

Fig. 15. Photomicrographs of the untreated (left) and treated (right) JSB sample

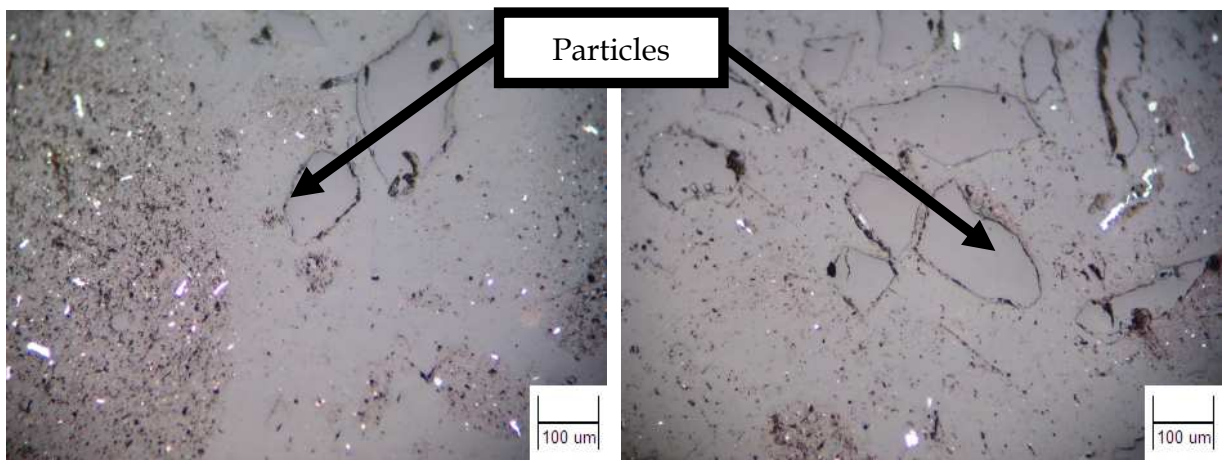

Fig. 16. Photomicrographs of the untreated (left) and treated (right) JSD sample 


\subsection{Electrical properties and surface colour changes}

The transfer of RF power to the rock samples resulted in a surface temperature rise due to RF heating of the dielectric material. Table 3 presents visual effects of RF heating on the three rock samples (JSA, JSB and JSD), as well as the temperature reached after a specified time of RF treatment.

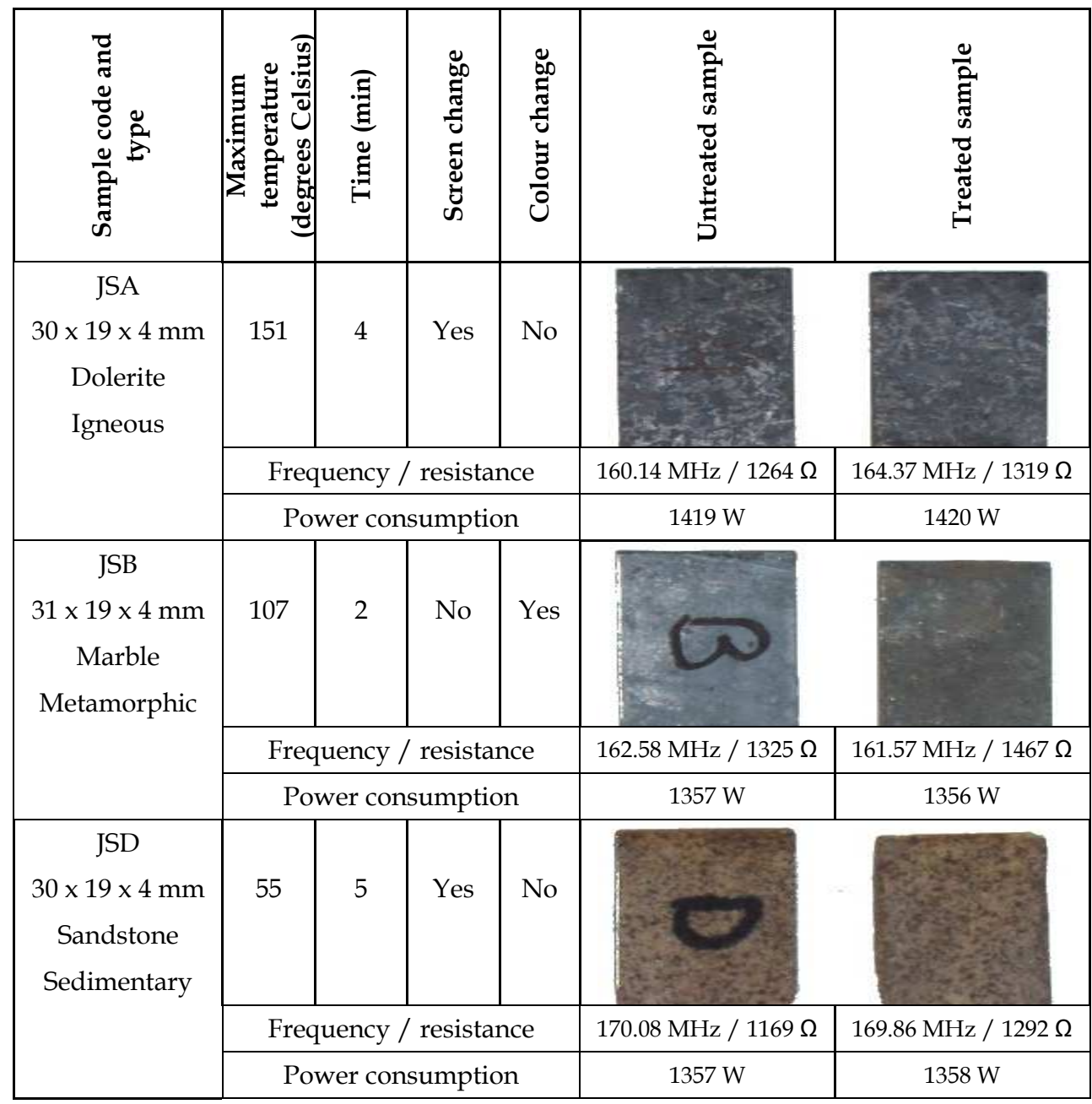

Table 3. Surface colour changes and maximum temperatures reached for samples JSA, JSB and JSD (untreated on the left and treated on the right)

Colour changes and maximum temperature reached with $82 \mathrm{~W}$ of RF power at $160 \mathrm{MHz}$ is indicated. S-parameters (in the form of Cartesian Coordinates) for the rock samples were obtained from a network analyser, from which the resonating frequencies and resistances were calculated for the untreated and treated rock samples. No significant variations were 
observed between the untreated and treated samples with regard to two of their electrical properties, being the resonating frequencies and resistances. The power consumption (sum of the power consumed by the RF equipment and milling machine) of the untreated and treated samples also reveals no significant variations.

\section{Conclusion}

One of the primary aims of this research was to design and develop a suitable coupling device to connect relevant electronic equipment (test instruments and amplifiers) to various rock samples. Maximum power transfer to the rock sample at a specific frequency was achieved with the use of a PPC and matching network housed in a novel wooden jig. Inserting specific sized rock samples into this coupling device proved simple and effective, being neither time consuming or difficult.

Only two of the three samples (JSA and JSD) revealed a notable change in their particle size distribution. The fact that the percentage of larger sized particles increased (from $38 \mu \mathrm{m}$ to $90 \mu \mathrm{m}$ ) suggests that the rock was strengthened rather than weakened (see Fig. 11 and Fig. 13). A possible application could be the prevention of over-grinding during comminution, which may have benefits during mineral processing. Moreover, RF power could further be used in the colouring of rock surfaces (see Table 3).

Evaluating the effects of RF power treatment on rocks has brought to light that mineral grain boundaries within specified rock samples are not significantly weakened by RF treatment. This was firstly confirmed by the similar electrical properties of the untreated and treated samples, where consistent values for the resonating frequency were obtained from a network analyser. Secondly, the SEM analysis of the untreated and treated rock samples revealed no significant changes in the form of fractures or breakages along the mineral grain boundaries. Photomicrographs of the thin sections of the two rock samples were used in this analysis. The particle size distribution of both samples further revealed no weakening or softening of the rock, as the percentage of smaller sized particles did not increase in the treated samples. It may therefore be stated that treating rock samples with RF power within the VHF range will not significantly improve rock comminution and mineral liberation.

\section{Acknowledgment}

I acknowledge Prof. Christo Pienaar (Director of the Telkom Centre of Excellence) for his specific guidance relating to the methodology employed in this research. I also would like to acknowledge Prof. Peter Mendonidis (Principal Lecturer in Metallurgical Engineering at Vaal University of Technology) for explaining difficult terms and principles relating to rock comminution. I further acknowledge my colleague, Ruaan Schoeman, who often provided a listening ear to my concerns and battles regarding this research. Appreciation is also extended to the Central Research Committee at VUT for their financial contribution to this research.

\section{References}

Aloian, M. (2010). What are igneous rocks. New York: Crabtree Publishing Company. 
Amankwah, R. K., Khan, A. U., Pickles, C. A., \& Yen, W. T. (2005). Improved grindability and gold liberation by microwave pretreatment of a free-milling gold ore. International Journal of Mineral Processing and Extractive Metallurgy Review, Vol. 114, No. C, pp. 30-36, ISSN 0882-7508

Andres, U., Timoshkin, I., \& Soloviev, M. (2001). Energy consumption and liberation of minerals in explosive electrical breakdown of ores. Mineral Processing and Extractive Metallurgy: Transactions of the Institute of Mining and Metallurgy, Section C, Vol. 110, No., pp. 149-157, ISSN 0371-9553

Azimi, P., \& Golnabi, H. (2009). Precise formulation of electrical capacitance for a cylindrical capacitive sensor. Journal of Applied Science, Vol., No. 9, pp. 1556-1561, ISSN 18125654

Bagdassarov, N. S., \& Slutskii, A. B. (2003). Phase transformations in calcite from electrical impedance measurements. Phase Transitions: A Multinational Journal, Vol. 76, No. 12, pp. 1015 - 1028, ISSN 0141-1594

Baker, R. J., \& Johnson, B. P. (1993). Applying the Marx bank circuit configuration to power MOSFETs. Electronics Letters, Vol. 29, No. 1, pp. 56-57, ISSN 0013-5194

Best, M. G., \& Christiansen, E. H. (2001). Igneous Petrology. Massachusetts: Blackwell Science. Bradshaw, S. M., van Wyk, E. J., \& de Swardt, J. B. (1998). Microwave heating principles and the application to the regeneration of granular activated carbon. The Journal of The South African Institute of Mining and Metallurgy, Vol. July/August, No., pp. 201-210, ISSN 0038-223X

Carlson, D. H., Plummer, C. C., \& McGeary, D. (2008). Physical Geology: Earth Revealed (7th ed.). New York: McGraw-Hill.

Chee, S. N., Johansen, A. L., Gu, L., Karlsen, J., \& Heng, P. W. S. (2005). Microwave Drying of Granules Containing a Moisture-Sensitive Drug: A Promising Alternative to Fluid Bed and Hot Air Oven Drying. Chemical \& Pharmaceutical Bulletin, Vol. 53, No. 7, pp. 770-775, ISSN 0009-2363

Chen, T. T., Dutrizac, J. E., Haque, K. E., Wyslouzil, W., \& Kashyap, S. (1984). The relative transparency of minerals to microwave radiation. Canadian Metallurgical Quarterly, Vol. 23, No. 3, pp. 349-351, ISSN 0008-4433

Chernicoff, S., \& Fox, H. A. (1997). Essential of Geology. New York: Worth Publishers.

Cho, S. H., Mohanty, B., Ito, M., Nakamiya, Y., Owada, S., Kubota, S., et al. (2006). Dynamic fragmentation of rock by high-voltage pulses. Paper presented at the The 41st U.S. Symposium on Rock Mechanics (USRMS), Golden, Colorado. June 17-21

De Waal, P. (2007). Tomorrow's Technology - Out of Africa - Today. Paper presented at the The Fourth Southern African Conference on Base Metals, Swakopmund, Namibia. 23-25 July

Dev, S. R. S., Padmini, T., Adedeji, A., Gariepy, Y., \& Raghavan, G. S. V. (2008). A comparative study on the effect of chemical, microwave, and pulsed electric pretreatments on convective drying and quality of raisins. Drying Technology, Vol. 26, No. 10, pp. 1238-1243, ISSN 07373937

Dietrich, R. V., \& Skinner, B. J. (1979). Rocks and rock minerals. New York: John Wiley and Sons.

Evans, I. O. (1972). Rocks, Minerals \& Gemstones. London: The Hamlyn Publishing Group. 
Fontana, R. J. (2004). Recent System Applications of Short-Pulse Ultra-Wideband (UWB) Technology. IEEE Transactions on Microwave Theory and Techniques, Vol. 52, No. 9, pp. 2087-2104, ISSN 0018-9480

Gaete-Garretón, L., Vargas-Hernandez, Y., Chamayou, A., Dodds, J. A., Valderama-Reyes, W., \& Montoya-Vitini, F. (2003). Development of an ultrasonic high-pressure roller press. Chemical Engineering Science, Vol. 58, No. 19, pp. 4317-4322, ISSN 0009-2509

Gaete-Garretón, L. F., Vargas-Hermández, Y. P., \& Velasquez-Lambert, C. (2000). Application of ultrasound in comminution. Ultrasonics, Vol. 38, No. 1-8, pp. 345352, ISSN 0041-624X

Gärtner, W. (1953). Über die Möglichkeit der zerkleinerung suspendierter stoffe durch ultrashall. Acustica, Vol. 3, No., pp. 124-128, ISSN 1610-1928

Giancoli, D. C. (2005). Physics - principles with applications (6th Ed ed.). New Jersey: Pearson Prentice Hall.

Halverson, S. L., Burkholder, W. E., Bigelow, T. S., Norsheim, E. V., \& Misenheimer, M. E. (1996). High-power microwave radiation as an alternative insect control method for stored products. J. Econ. Entomol, Vol. 89, No., pp. 1638-1648, ISSN 0022-0493

Henan Chuangxin Building-material Equipment Co. (2009). Retrieved 6 November 2009, from http:/ / www.enchuangxin.com/Mineral\%20Processing\%20Equipment/

$\mathrm{Hu}$, Z., Wang, Y., \& Wen, Z. (2008). Alkali (NaOH) pretreatment of switchgrass by radio frequency-based dielectric heating. Applied Biochemistry and Biotechnology, Vol. 148, No. 1-3, pp. 71-81, ISSN 0273-2289

Hu, Z., \& Wen, Z. (2008). Enhancing enzymatic digestibility of switchgrass by microwaveassisted alkali pretreatment. Biochemical Engineering Journal, Vol. 38, No. 3, pp. 369378, ISSN 1369-703X

Hutchinson, C. (Ed.). (2001). The ARRL Handbook for Radio Amateurs (78th ed.). Newington: ARRL.

Ikediala, J. N., Hansen, J. D., Tang, J., Drake, S. R., \& Wang, S. (2002). Development of a saline water immersion technique with RF energy as a postharvest treatment against codling moth in cherries. Postharvest Biology and Technology, Vol. 24, No., pp. 209-221, ISSN 0925-5214

Jones, D. A., Kingman, S. W., Whittles, D. N., \& Lowndes, I. S. (2007). The influence of microwave energy delivery method on strength reduction in ore samples. Chemical Engineering and Processing, Vol. 46, No. 4, pp. 291-299, ISSN 0255-2701

Jones, D. A., Lelyveld, T. P., Mavrofidis, S. D., Kingman, S. W., \& Miles, N. J. (2002). Microwave heating applications in environmental engineering--a review. Resources, Conservation and Recycling, Vol. 34, No. 2, pp. 75-90, ISSN 0921-3449

Kawala, Z., \& Atamanczuk, T. (1998). Microwave-enhanced thermal decontamination of soil. Environmental Science and Technology, Vol. 32, No. 17, pp. 2602-2607, ISSN 0013936X

Kelly, R. M., \& Rowson, N. A. (1995). Microwave reduction of oxidised ilmenite concentrates. Minerals Engineering, Vol. 8, No. 11, pp. 1427-1438, ISSN 0892-6875

King, R. P. (2001). Modelling and simulation of mineral processing systems. Oxford: ButterworthHeinemann. 
Kingman, S. W., Jackson, K., Cumbane, A., Bradshaw, S. M., Rowson, N. A., \& Greenwood, R. (2004). Recent developments in microwave-assisted comminution. Int. J. Min. Proc, Vol. 74, No. 1-4, pp. 71-83, ISSN 1478-6478

Klein, C. (2002). The 22nd edition of the manual of Mineral Science. New York: John Wiley \& Sons.

Kostaropoulos, A. E., \& Saravacos, G. D. (1995). Microwave Pre-treatment for Sun-Dried Raisins. Journal of Food Science, Vol. 60, No. 2, pp. 344-347, ISSN 1750-3841

Leach, M. F., \& Rubin, G. A. (1988). Fragmentation of Rocks Under Ultrasonic Loading. Paper presented at the Ultrasonic Symp of the IEEE, Chicago, USA. 2-5 October

Leaman, D. E. (1973). The engineering properties of Tasmanian dolerite, with particular reference to the route of the Bell Bay Railway, Tasm. Dep. Mines. Tech. Rept.

Levitskaya, T. M., \& Sternberg, B. K. (2000). Laboratory measurement of material electrical properties: extending the application of lumped-circuit equivalent models to 1 GHz. Radio Science, Vol. 35, No. 2, pp. 371-383, ISSN 0048-6604

Li, X., Zhang, B., Li, W., \& Li, Y. (2005). Research on the effect of microwave pretreatment on moisture diffusion coefficient of wood. Wood Science and Technology, Vol. 39, No. 7, pp. 521-528, ISSN 0043-7719

McGeary, D., Plummer, C. C., \& Carlson, D. (2001). Physical Geology EARTH REVEALED (4th ed.). New York: WCB/McGraw-Hill.

Montalbo-Lomboy, M., Srinivasan, G., Raman, D. R., Anex Jr, R. P., \& Grewell, D. (2007). Influence of ultrasonics in ammonia steeped switchgrass for enzymatic hydrolysis. Paper presented at the 2007 ASABE Annual International Meeting, Technical Papers, Minneapolis, MN, United states. 17-20 June

Moran, C. (2009). Submission to the Australian Government Energy White Paper. Retrieved 7 July 2011. From

http:/ / www.ret.gov.au/energy/Documents/ewp/pdf/EWP\%200047\%20DP\%20S ubmission \%20-\%20Sustainable\%20Minerals\%20Institute.pdf.

Nelson, S. O. (1996). Review and assessment of RF and microwave energy for stored-grain insect control. Trans. ASAE, Vol. 39, No., pp. 1475-1484, ISSN 0001-2351

Nitayavardhana, S., Rakshit, S. K., Grewell, D., Van Leeuwen, J., \& Khanal, S. K. (2008). Ultrasound pretreatment of cassava chip slurry to enhance sugar release for subsequent ethanol production. Biotechnology and Bioengineering, Vol. 101, No. 3, pp. 487-496, ISSN 0006-3592

Owada, S., Ito, M., Ota, T., Nishimura, T., Ando, T., Yamashita, T., et al. (2003). Application of electrical disintegration to coal. Paper presented at the 22th International Mineral Processing Congress, Cape Town, South Africa. 28 September - 3 October

Pan, S., Lo, K. V., Ping, H. L., \& Schreier, H. (2006). Microwave pretreatment for enhancement of phosphorus release from dairy manure. Journal of Environmental Science and Health - Part B Pesticides, Food Contaminants, and Agricultural Wastes, Vol. 41, No. 4, pp. 451-458, ISSN 0360-1234

Peng, B., Shi, B., Sun, D., Chen, Y., \& Shelly, D. C. (2007). Ultrasonic effects on titanium tanning of leather. Ultrasonics Sonochemistry, Vol. 14, No. 3, pp. 305-313, ISSN 13504177

Perkins, D. (1998). Mineralogy. New Jersey: Prentice Hall. 
Pienaar, H. C. (2002). Design and development of a class E dielectric blood heater. DTech, Vaal Triangle Technikon, Vanderbijlpark.

Pozar, D. M. (2005). Microwave Engineering (3rd ed.). Massachusetts: John Wiley \& Sons.

Rapp, G. (2009). Properties of Minerals. In B. Herrmann \& G. A. Wagner (Eds.), Archaeomineralogy (pp. 17-43): Springer Berlin Heidelberg.

Roland, U., Buchenhorst, D., Holzer, F., \& Kopinke, F. D. (2008). Engineering Aspects of Radio-Wave Heating for Soil Remediation and Compatibility with Biodegradation. Environmental Science E Technology, Vol. 42, No. 4, pp. 1232-1237, ISSN 0013-936X

Roy, I., Mondal, K., \& Gupta, M. N. (2003). Accelerating Enzymatic Hydrolysis of Chitin by Microwave Pretreatment. Biotechnology Progress, Vol. 19, No. 6, pp. 1648-1653, ISSN 8756-7938

Rutschlin, M., Cloete, J. H., \& Palmer, K. D. (2006). A guarded cylindrical capacitor for the non-destructive measurement of hard rock core samples. Measurement Science and Technology, Vol. 17, No. 6, pp. 1390-1398, ISSN 0957-0233

Sadrai, S., Meech, J. A., Ghomshei, M., Sassani, F., \& Tromans, D. (2006). Influence of impact velocity on fragmentation and the energy efficiency of comminution. International Journal of Impact Engineering, Vol. 33, No. 1-12, pp. 723-734, ISSN 0734-743X

Scott, G., Bradshaw, S. M., \& Eksteen, J. J. (2008). The effect of microwave pretreatment on the liberation of a copper carbonatite ore after milling. International Journal of Mineral Processing, Vol. 85, No., pp. 121-128, ISSN 0301-7516

Shafiee, S., \& Topal, E. (2009). When will fossil fuel reserves be diminished? Energy Policy, Vol. 37, No. 1, pp. 181-189, ISSN 0301-4215

Skinner, B. J., \& Porter, S. C. (1992). The Dynamic Earth an introduction to physical geology (2nd ed.). New York: John Wiley \& Sons.

Smith, R. D. (1993). Large industrial microwave power supplies. Paper presented at the Proc. Microwave-Induced reactions workshops, Pacific Grove, California. April

Spierings, E. L. H., Brevard, J. A., \& Katz, N. P. (2008). Two-Minute Skin Anesthesia Through Ultrasound Pretreatment and Iontophoretic Delivery of a Topical Anesthetic: A Feasibility Study. Pain Medicine, Vol. 9, No. 1, pp. 55-59, ISSN 15262375

Staszewski, L. (2010). Lightning Phenomenon - Introduction and Basic Information to Understand the Power of Nature. Paper presented at the International Conference Environment and Electrical Engineering 2010, Prague, Czech Republic. 16-19 May

Swart, A. J., Pienaar, H. C. v., \& Mendonidis, P. (2005). Radio frequencies effect on rock comminution. Paper presented at the Annual Faculty Research Seminar, Vaal University of Technology, Emfuleni Conference Centre, Vanderbijlpark. July 2005

Swart, J., Mendonidis, P., \& Pienaar, C. (2009). The Electrical Properties of Chlorite Tremolite Marble measured for a range of Radio-Frequencies. Mineral Processing and Extractive Metallurgy Review: An International Journal, Vol. 30, No. 4, pp. 307 326, ISSN 0882-7508

Tarbuck, E. J., \& Lutgens, F. K. (1999). Earth An introduction to physical geology (6th ed.). New Jersey: Prentice Hall.

Thompson, G. R., \& Turk, J. (2007). Earth Science and the Environment (4th ed.). Belmont: Thompson Brooks/Cole. 
Tiedt, L. R., \& Pretorius, W. E. (2002). An introduction to electron microscopy and x-ray microanalysis [Electronic Version]. Laboratory for Electron Microscopy, North-West University.

Tiehm, A., Nickel, K., \& Neis, U. (1997). The use of ultrasound to accelerate the anaerobic digestion of sewage sludge. Water Science and Technology, Vol. 36, No., pp. 121-128, ISSN 0273-1223

Touryan, K. J., \& Benze, J. W. (1991). Enhanced Coal Comminution And Beneficiation using Pulsed Power Generated Shocks. Paper presented at the Pulsed Power Conference, 8th IEEE International, San Diego, California. 16-19 June

Tromans, D. (2008). Mineral comminution: Energy efficiency considerations. Minerals Engineering, Vol. 21, No. 8, pp. 613-620, ISSN 0892-6875

Uquiche, E., Jerez, M., \& Ortiz, J. (2008). Effect of pretreatment with microwaves on mechanical extraction yield and quality of vegetable oil from Chilean hazelnuts (Gevuina avellana Mol). Innovative Food Science and Emerging Technologies, Vol. 9, No. 4, pp. 495-500, ISSN 1466-8564

Walkiewicz, J. W., Kazonich, G., \& McGill, S. L. (1988). Microwave heating characteristics of selected minerals and compounds. Minerals and Metallurgical Processing, Vol., No., pp. 39-42, ISSN 0747-9182

Walther, J. V. (2005). Essentials of geochemistry. Massachusetts: Jones \& Bartlett Publishers.

Wang, S., Birla, S. L., Tang, J., \& Hansen, J. D. (2006). Postharvest treatment to control codling moth in fresh apples using water assisted radio frequency heating. Postharvest Biology and Technology, Vol. 40, No. 1, pp. 89-96, ISSN 0925-5214

Wang, S., Ikediala, J. N., Tang, J., Hansen, J. D., Mitcham, E., Mao, R., et al. (2001). Radio frequency treatments to control codling moth in in-shell walnuts. Postharvest Biology and Technology, Vol. 22, No., pp. 29-38, ISSN 0925-5214

Wang, Y., \& Forssberg, E. (2007). Enhancement of energy efficiency for mechanical production of fine and ultra-fine particles in comminution. China Particuology, Vol. 5, No. 3, pp. 193-201, ISSN 1672-2515

Wenk, H. R., \& Bulakh, A. (2004). Minerals their Constitution and Origin. Cambridge: Cambridge University Press.

Wills, B. A. (1992). Mineral processing technology (5th ed.). Oxford: Pergamon Press.

Wilson, M. P., Balmer, L., Given, M. J., MacGregor, S. J., Mackersie, J. W., \& Timoshkin, I. V. (2006). Application of electric spark generated high power ultrasound to recover ferrous and non-ferrous metals from slag waste. Minerals Engineering, Vol. 19, No. 5, pp. 491-499, ISSN 0892-6875

Winands, G. J. J., Liu, Z., Pemen, A. J. M., van Heesch, E. J. M., \& Yan, K. (2005). Long lifetime, triggered, spark-gap switch for repetitive pulsed power applications. Review of Scientific Instruments, Vol. 76, No. 8, pp. 085107-085106, ISSN 0034-6748

Wolde-Rufael, Y. (2010). Coal consumption and economic growth revisited. Applied Energy, Vol. 87, No. 1, pp. 160-167, ISSN 0306-2619

Woollacott, L. C., \& Eric, R. H. (1994). Mineral and metal extraction: an overview. Johannesburg: The South African Institute of Mining and Metallurgy.

Yerkovic, C., Menacho, J., \& Gaete, L. (1993). Exploring the ultrasonic comminution of copper ores. Minerals Engineering, Vol. 6, No. 6, pp. 607-617, ISSN 0892-6875 
Zaghloul, M. R. (2008). A simple theoretical approach to calculate the electrical conductivity of nonideal copper plasma. Physics of Plasmas, Vol. 15, No. 4, pp. 701-705, ISSN 1070-664X

Zhang, W., \& Yao, Y. L. (2002). Micro scale laser shock processing of metallic components. Journal of Manufacturing Science and Engineering Transactions of ASME, Vol. 124, No., pp. 369-378, ISSN 1087-1357 


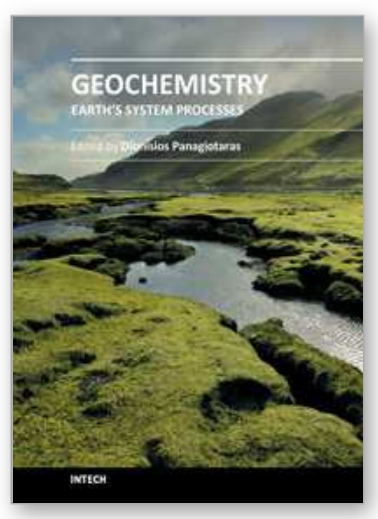

\author{
Geochemistry - Earth's System Processes \\ Edited by Dr. Dionisios Panagiotaras
}

ISBN 978-953-51-0586-2

Hard cover, 500 pages

Publisher InTech

Published online 02, May, 2012

Published in print edition May, 2012

This book brings together the knowledge from a variety of topics within the field of geochemistry. The audience for this book consists of a multitude of scientists such as physicists, geologists, technologists, petroleum engineers, volcanologists, geochemists and government agencies. The topics represented facilitate as establishing a starting point for new ideas and further contributions. An effective management of geological and environmental issues requires the understanding of recent research in minerals, soil, ores, rocks, water, sediments. The use of geostatistical and geochemical methods relies heavily on the extraction of this book. The research presented was carried out by experts and is therefore highly recommended to scientists, underand post-graduate students who want to gain knowledge about the recent developments in geochemistry and benefit from an enhanced understanding of the dynamics of the earth's system processes.

\title{
How to reference
}

In order to correctly reference this scholarly work, feel free to copy and paste the following:

Arthur James Swart (2012). Evaluating the Effects of Radio-Frequency Treatment on Rock Samples: Implications for Rock Comminution, Geochemistry - Earth's System Processes, Dr. Dionisios Panagiotaras (Ed.), ISBN: 978-953-51-0586-2, InTech, Available from: http://www.intechopen.com/books/geochemistryearth-s-system-processes/evaluating-the-effects-of-rf-treatment-on-rock-samples-implications-for-rockcomminution

\section{INTECH}

open science | open minds

\author{
InTech Europe \\ University Campus STeP Ri \\ Slavka Krautzeka 83/A \\ 51000 Rijeka, Croatia \\ Phone: +385 (51) 770447 \\ Fax: +385 (51) 686166 \\ www.intechopen.com
}

\author{
InTech China \\ Unit 405, Office Block, Hotel Equatorial Shanghai \\ No.65, Yan An Road (West), Shanghai, 200040, China \\ 中国上海市延安西路65号上海国际贵都大饭店办公楼 405 单元 \\ Phone: +86-21-62489820 \\ Fax: $+86-21-62489821$
}


(C) 2012 The Author(s). Licensee IntechOpen. This is an open access article distributed under the terms of the Creative Commons Attribution 3.0 License, which permits unrestricted use, distribution, and reproduction in any medium, provided the original work is properly cited. 